NASA/TM-2003-212212
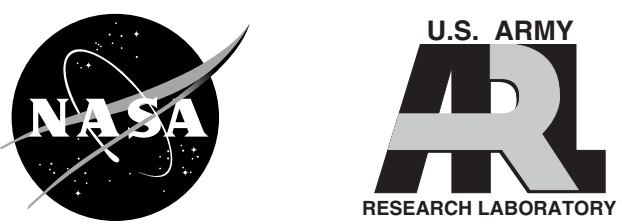

\title{
Design of Aspirated Compressor Blades Using Three-Dimensional Inverse Method
}

T.Q. Dang and M. Van Rooij

Syracuse University, Syracuse, New York

L.M. Larosiliere

U.S. Army Research Laboratory, Glenn Research Center, Cleveland, Ohio 
Since its founding, NASA has been dedicated to the advancement of aeronautics and space science. The NASA Scientific and Technical Information (STI) Program Office plays a key part in helping NASA maintain this important role.

The NASA STI Program Office is operated by Langley Research Center, the Lead Center for NASA's scientific and technical information. The NASA STI Program Office provides access to the NASA STI Database, the largest collection of aeronautical and space science STI in the world. The Program Office is also NASA's institutional mechanism for disseminating the results of its research and development activities. These results are published by NASA in the NASA STI Report Series, which includes the following report types:

- $\quad$ TECHNICAL PUBLICATION. Reports of completed research or a major significant phase of research that present the results of NASA programs and include extensive data or theoretical analysis. Includes compilations of significant scientific and technical data and information deemed to be of continuing reference value. NASA's counterpart of peerreviewed formal professional papers but has less stringent limitations on manuscript length and extent of graphic presentations.

- TECHNICAL MEMORANDUM. Scientific and technical findings that are preliminary or of specialized interest, e.g., quick release reports, working papers, and bibliographies that contain minimal annotation. Does not contain extensive analysis.

- CONTRACTOR REPORT. Scientific and technical findings by NASA-sponsored contractors and grantees.
- CONFERENCE PUBLICATION. Collected papers from scientific and technical conferences, symposia, seminars, or other meetings sponsored or cosponsored by NASA.

- SPECIAL PUBLICATION. Scientific, technical, or historical information from NASA programs, projects, and missions, often concerned with subjects having substantial public interest.

- TECHNICAL TRANSLATION. Englishlanguage translations of foreign scientific and technical material pertinent to NASA's mission.

Specialized services that complement the STI Program Office's diverse offerings include creating custom thesauri, building customized databases, organizing and publishing research results ... even providing videos.

For more information about the NASA STI Program Office, see the following:

- Access the NASA STI Program Home Page at http://www.sti.nasa.gov

- E-mail your question via the Internet to help@sti.nasa.gov

- Fax your question to the NASA Access Help Desk at 301-621-0134

- Telephone the NASA Access Help Desk at 301-621-0390

- Write to:

NASA Access Help Desk

NASA Center for AeroSpace Information 7121 Standard Drive

Hanover, MD 21076 
NASA/TM-2003-212212

ARL-TR-2957
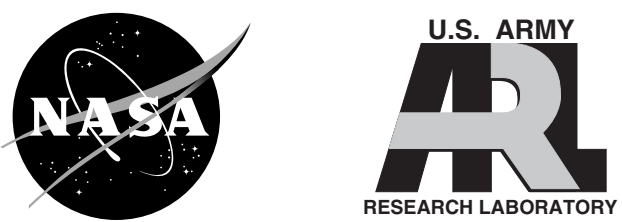

GT-2003-38492

\section{Design of Aspirated Compressor Blades Using Three-Dimensional Inverse Method}

T.Q. Dang and M. Van Rooij

Syracuse University, Syracuse, New York

L.M. Larosiliere

U.S. Army Research Laboratory, Glenn Research Center, Cleveland, Ohio

Prepared for the

Turbo Expo 2003

cosponsored by the American Society of Mechanical Engineers

and the International Gas Turbine Institute

Atlanta, Georgia, June 16-19, 2003

National Aeronautics and

Space Administration

Glenn Research Center 


\section{Acknowledgments}

This work was partially funded by NASA under the Ultra Efficient Engine Technology (UEET) Project. Sincere gratitude is offered to M.D. Hathaway and K.L. Suder at NASA Glenn Research Center, for their technical support of this effort. The authors thank Pointwise, Inc. for providing the grid-generation software Gridgen.

Available from

NASA Center for Aerospace Information 7121 Standard Drive

Hanover, MD 21076
National Technical Information Service 5285 Port Royal Road Springfield, VA 22100

Available electronically at http:/ /gltrs.grc.nasa.gov 


\title{
DESIGN OF ASPIRATED COMPRESSOR BLADES USING THREE-DIMENSIONAL INVERSE METHOD
}

\author{
T.Q. Dang and M. Van Rooij \\ Syracuse University \\ Syracuse, New York 13244 \\ L.M. Larosiliere \\ U.S. Army Research Laboratory \\ Glenn Research Center \\ Cleveland, Ohio 44135
}

\begin{abstract}
A three-dimensional viscous inverse method is extended to allow blading design with full interaction between the prescribed pressure-loading distribution and a specified transpiration scheme. Transpiration on blade surfaces and endwalls is implemented as inflow/outflow boundary conditions, and the basic modifications to the method are outlined. This paper focuses on a discussion concerning an application of the method to the design and analysis of a supersonic rotor with aspiration. Results show that an optimum combination of pressure-loading tailoring with surface aspiration can lead to a minimization of the amount of sucked flow required for a net performance improvement at design and off-design operations.
\end{abstract}

\section{INTRODUCTION}

Turbo-compression technology has been advanced continuously by higher work capacity per stage as a result of increases in rotor speed, aerodynamic loading, and throughflow Mach numbers. With the advent of sophisticated diagnostic tools involving CFD and measurement techniques, more suitable blade shapes having relatively low losses at higher diffusion and Mach number levels have been deployed. While incremental performance advancements can be made through geometric optimization and improved design methods, severe aerodynamic limitations such as increased losses and decreased operability are often encountered when attempting to push significantly beyond current loading levels. Thus, techniques for achieving low losses with wide operability at increased aerodynamic loading levels have received renewed interest $[1,2]$.

As shown by Loughery et al. [3], surface transpiration, properly focused, can be effective at mitigating some deleterious effects associated with increased aerodynamic loading of compressor blades. Surface transpiration is effected either through suction (i.e., aspiration) or blowing of a relatively small amount of flow along the blade or endwall surfaces. Various tactics are possible including controlling profile aerodynamics with or without shocks, managing secondary flows, and tailoring profile and endwall aerodynamic interactions. To effectively execute these schemes in an optimal sense, not only requires a good understanding of the underlying mechanisms but also availability of effective design tools. In this paper, a CFD tool that can be used to design compressor blades with surface flow transpiration is described. The proposed method is an extension of a three-dimensional inverse method reported by Dang et al. [4] and Medd [5], whereby the blade pressure loading distribution is prescribed and the derived quantity is the three-dimensional blade camber surface. Transpiration boundary conditions are incorporated within this framework, thereby allowing full interaction between the prescribed pressure loading distribution and the transpiration scheme.

Following a brief exposition of the method, this paper focuses on a discussion concerning the aerodynamic design and performance aspects of a highly-loaded supersonic rotor with aspiration. The intent is not to develop a complete aspirated rotor design that can be manufactured and experimentally tested, but rather to showcase the utility of the inverse method. In general, aspiration is used as an add-on to improve operability of highly-loaded blades and tends to suffer from large sucked flow rate requirements and lack of a unified approach to aspirated transonic blading design. Herein, the blade design objective is an optimum combination of pressureloading tailoring with surface aspiration resulting in a minimal amount of sucked flow for a net aerodynamic performance improvement at design and off-design operations. 


\section{NOMENCLATURE}

$C_{Q} \quad$ suction coefficient, (suction mass flow rate)/(inlet mass flow rate)

$f \quad$ blade mean camber line or wrap angle

$p_{a} \quad$ reference pressure

$p_{b} \quad$ rotor back pressure

$P_{0} \quad$ stagnation pressure

$T_{0} \quad$ stagnation temperature

$W_{a s p, n}$ transpirated velocity component normal to blade surface

$\Delta p \quad$ local blade pressure-loading or pressure difference across blade

$\eta \quad$ adiabatic efficiency

Superscripts:

$+\quad$ blade upper surface

- blade lower surface

Subscripts:

1 rotor inlet station

2 rotor outlet station

asp station denoting blade surface aspirated region

\section{ANALYSIS AND INVERSE METHODS}

The computer code, INV3D, used for the design and analysis conducted herein is fully described in Medd [5], including assessments of viscous modeling accuracy. It is based on the solution of the three-dimensional Reynolds-Averaged Navier-Stokes equations using the robust finite-volume timemarching cell-centered scheme of Jameson et al. [6]. To facilitate quick-look scoping, an option to compute the quasithree-dimensional flow in a blade element situated between two pseudo streamwise grid lines was added to INV3D. Viscous effects are modeled using wall functions with an adaptation of the Baldwin-Lomax turbulence closure. The viscous method implemented in INV3D employs a "slip" velocity at solid boundaries. This "slip" velocity is used in the inverse mode to trace the camber surface. The argument here is that if the viscous sub-layer is neglected, the first cell next to solid boundaries lies in the logarithmic region and hence the velocity is finite [7]. Typical viscous calculations using INV3D employ $\mathrm{y}+$ on the order of 100 .

Flow transpiration on the blade surfaces and along endwalls is implemented as inflow/outflow boundary conditions. Consistent with the time-marching algorithm used in INV3D, boundary conditions are imposed as follows. For flow aspiration or suction, one boundary condition needs to be prescribed while the remaining quantities are extrapolated from the interior points. In the present method, assuming that the flow is not choked, the suction mass flow rate per unit area (or $\left.\rho W_{a s p, n}\right)$ is prescribed and is distributed uniformly over the specified aspiration zone. Clearly, the distribution of suction mass flux over the aspiration zone depends on the details of the internal flow circuit of a particular aspiration scheme. Although the present study assumes uniform mass flux, an arbitrary distribution can easily be implemented. The remaining four quantities extrapolated from the interior domain include the two velocity components tangent to the surface, the static pressure, and the density.

For flow injection or blowing, four quantities are prescribed and the remaining quantity is extrapolated from the interior domain. In the present method, the blowing mass flow rate per unit area is again prescribed and distributed uniformly over the blowing zone. In addition, the total temperature and two flow directions are prescribed, while the static pressure is extrapolated from the interior domain. Currently, the wall functions are not explicitly modified for the transpired boundary layer and the impact of this is not known.

The generalized, multi-block, Reynolds Averaged NavierStokes code, $A D P A C$ [8], was used to check the validity of the flow-transpiration model described above. Turbulence closure in $A D P A C$ is also achieved with an adaptation of the BaldwinLomax model and for the most part, the code has been shown to give reliable predictions of turbomachinery flows. It is noted that implementation of flow suction in $A D P A C$ is different from $I N V 3 D$. In particular, $A D P A C$ does provide an option for specifying the total suction mass flow rate with automatic adjustment of the uniform "back pressure" at the suction holes to obtain the prescribed mass flow rate. Hence, the suction mass flow rate per unit area is not necessarily uniform over the aspirated region unless the interface static pressure itself is uniform. This is usually the case in two dimensions with small axial slots. However, these two implementations can be very different in three dimensions because of spanwise pressure gradients. The multi-block capability in $A D P A C$ allows flow transpiration to be modeled by a flushed slot of finite length so that the boundary conditions can be imposed at the slot exit away from the throughflow region. Figure 1 illustrates a model that includes a portion of the slot flushed to the suction surface of the blade.

A blade section extracted from the supersonic rotor design to be described later was used for comparing the aspiration models. Both INV3D and ADPAC were executed in the quasithree-dimensional mode for the extracted blade element. The mesh size employed in this study consisted of 132 axial cells and 38 blade-to-blade cells, with 100 axial cells in the bladed region. An exit back pressure, $\mathrm{p}_{\mathrm{b}} / \mathrm{p}_{\mathrm{a}}=3.50$, corresponding to a spilled shock without aspiration, was set. Flow suction was then applied to pull the shock back inside the passage just ahead of the suction slot as indicated in Figure 1, and it was found by trial-and-error that flow suction in the amount of 2 percent of the entering mass flow rate (i.e., suction coefficient $\mathrm{C}_{\mathrm{Q}}=0.02$ ) is needed to achieve this objective. Figure 2 shows a comparison of surface static pressure distributions between $I N V 3 D$ and $A D P A C$ simulations with and without a slot. It can be observed that the static pressure distributions as predicted by the two codes are similar everywhere except in the vicinity of the suction region, and this difference is found to be small for moderate suction coefficients (i.e., $\mathrm{C}_{\mathrm{Q}}<5$ percent). Furthermore, the figure indicates that the implementations of flow suction with and without a slot are also very similar in terms of pressure loading and even local flow details (Fig. 1$A D P A C$ results). Finally, it was found that if the suction location is moved further downstream of the shock, INV3D and $A D P A C$ results with and without slot discretization are much closer in agreement than indicated in Figures 1 and 2. 


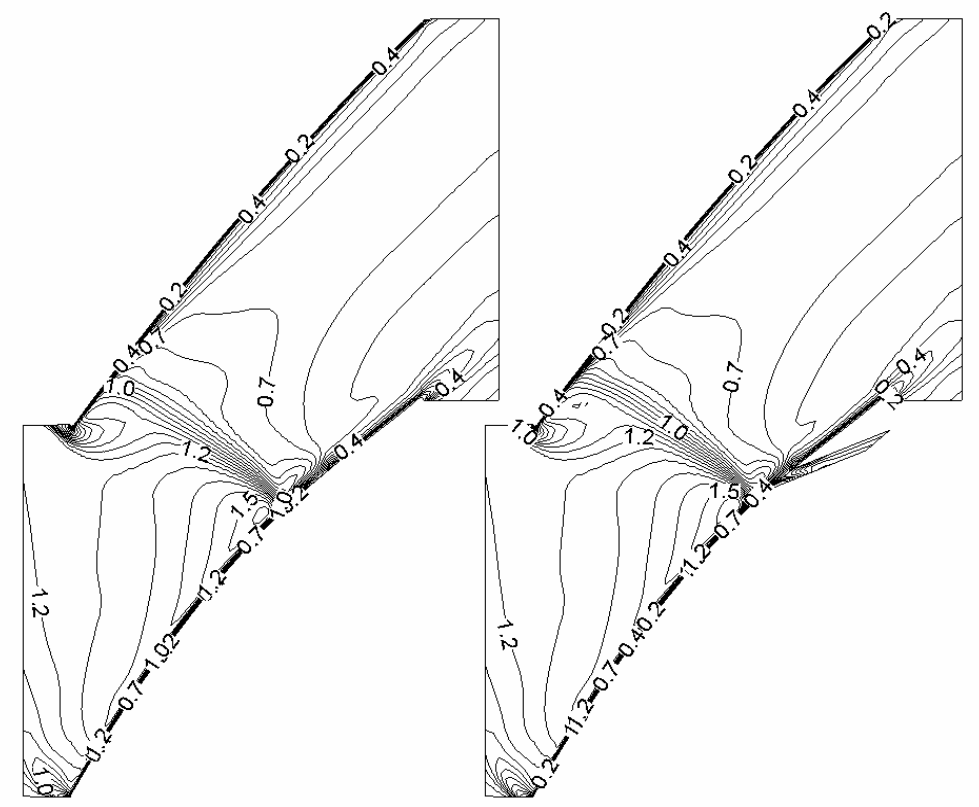

Figure 1.-Comparison of Mach number distribution for an aspirated supersonic rotor blade element without slot (left) and with slot (right) discretization using ADPAC.

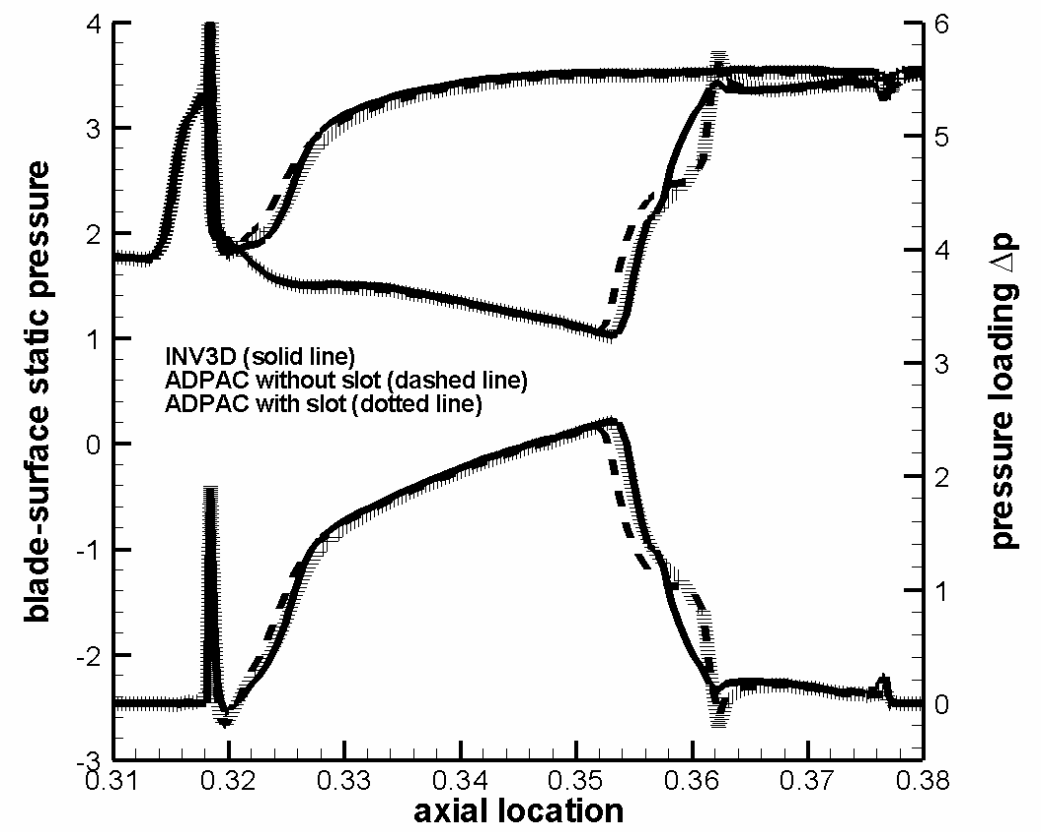

Figure 2.-Comparison of blade loading between INV3D and ADPAC simulations of an aspirated supersonic rotor blade element. 
The inverse design method employed here is an extension of a three-dimensional viscous inverse method reported in previous papers $[9,4,5,10,11]$. In this inverse technique, the primary prescribed quantities are the blade stacking line $f_{\text {stack }}=$ $f_{\text {stack }}(r)$, the blade thickness distribution $T=T(r, z)$, and the pressure loading distribution $\Delta p=\Delta p(r, z)$. Note that the pressure loading distribution is defined as the local pressure difference between lower and upper surfaces at fixed axial positions along the blade. Physically, at a given spanwise station, the area under the loading curve represents the net flux in angular momentum, $r V_{\theta}$ (or the local total temperature rise). For a given set of inputs, the three-dimensional inverse method computes the corresponding wrap angle $f=f(r, z)$ (or camber geometry) via the flow-tangency condition along the blade surfaces formulated as $\vec{W}^{ \pm} \cdot \hat{n}^{ \pm}=0$, where $\vec{W}$ is the relative velocity, $\hat{n}$ is the unit vector normal to the blade, and the superscripts + and - denote blade lower and upper surfaces, respectively. Clearly, the blade geometry corresponding to prescribed values for $\left[f_{\text {stack }}, T, \Delta p\right]$ is not guaranteed to have optimum performance nor be aeromechanically acceptable. The challenge is to pick these quantities to arrive at a satisfactory design. Successful pressure loading strategies for shock management in transonic bladings have been developed by Damle et al. [12] and Medd et al. [13]. Note that currently, the amount and location of flow transpiration is not derived by the inverse method, but is accounted for as prescribed by the user. Accounting for flow transpiration in the inverse mode is straightforward. Basically, the boundary condition along the blade surfaces is now $\vec{W}^{ \pm} \cdot \hat{n}^{ \pm}=W_{a s p, n}^{ \pm}$, and this flowtangency condition is used to develop the camber-surface generator. Here, $W_{a s p, n}^{ \pm}$is the prescribed transpirated velocity component normal to the blade surfaces. A detailed outline of the method is given by Medd [5].

\section{ASPIRATED ROTOR DESIGN AND PERFORMANCE}

A supersonic rotor, designated as $22-56$, from an advanced 2-stage design described in Larosiliere et al. [14] was selected as an appropriate candidate for exploring the potential of an integrated pressure-loading tailoring and aspiration scheme for improved performance at very high aerodynamic loadings. At the aerodynamic design point, the rotor inlet corrected tip speed is $1290 \mathrm{ft} / \mathrm{s}(393.2 \mathrm{~m} / \mathrm{s})$ and the inlet relative Mach number varies from about 1.1 at hub to nearly 1.4 at tip. This rotor consists of 56 blades with an average solidity of 1.96 and an aspect ratio of 0.86 . The design-intent duty is approximately a 2.05:1 total pressure ratio at an inlet mass flow rate of $72.5 \mathrm{lbm} / \mathrm{s}(32.9 \mathrm{~kg} / \mathrm{s})$, uncorrected for inlet aerodynamic blockage. Spanwise profiles of inflow conditions were taken from a throughflow model established in Larosiliere et al. [14].

Although the design point aerodynamic loading of the $R 2$ 56 blade is reasonably high, it's not at a critical state necessitating aspiration. To create a critical state, the blade count was reduced (42 blades versus 56 blades) thereby significantly increasing the adverse pressure gradient along the suction surface with an associated stronger shock. This blade, having the same shape as the $R 2-56$ blade but reduced solidity, is referred to as the original blade. As will be shown, the original blade requires an add-on aspiration scheme in order to

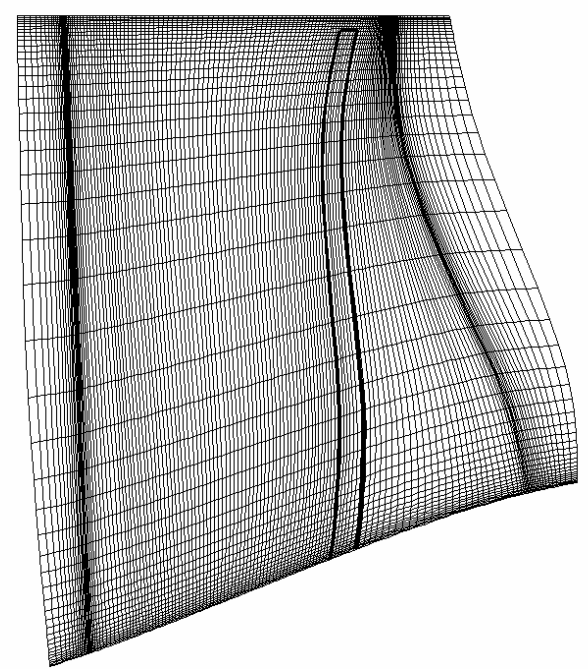

\section{Figure 3.-Meridional grid highlighting the aspirated zone on blade suction surface.}

match the design-intent of the $R 2-56$ blade. In this study, a custom-tailored pressure-loading distribution is developed and integrated with the aspiration scheme using the threedimensional inverse method and applied to the redesign of the original blade and the resulting geometry is designated as the new design.

The computed results to be presented were carried out using INV3D in both analysis and inverse modes with a mesh size of 142 by 48 by 34 cells (for a total of 232,000 cells). A simple sheared H-mesh was constructed using the commercial grid-generation software Gridgen which facilitated alignment of the meridional gridlines with the desired passage-shock position on the suction surface so that flow aspiration can be readily applied behind it (Fig. 3). Two cells are included in the tip-gap ( $\sim 1$ percent tip chord) which is not discretized but modeled by applying periodic boundary conditions across the extended blade surfaces. Note that INV3D results with more grid cells in the tip-gap did not justify the required expense in the context of this design study. For all the cases, the aspiration zone is located from the hub $(j=1)$ to 95 percent span $(j=41)$, and its axial extent is roughly 5 percent chord and encompasses 6 grid cells. For the current study, the outflow boundary condition was prescribed by setting the casing static pressure and employing simple radial equilibrium to obtain a spanwise profile. Using a Pentium $42.4 \mathrm{GHz} \mathrm{PC}$, a typical calculation running in the analysis mode takes about 2 hours to converge with 2,000 time steps, while the inverse mode takes about 10 percent longer.

A rational assessment of aspirated rotor efficiency should consider the work potential of the sucked flow relative to the overall system and its environment. We will not deal with this complex systems problem here; rather we will concentrate on the relative aerodynamic quality improvements. However, for comparison purpose, the following defined adiabatic efficiencies are computed for aspirated blades. The upper limit for adiabatic efficiency is defined as the case where the aspirated flow can be used fully (i.e., in a thermodynamic sense) and is expressed as: 


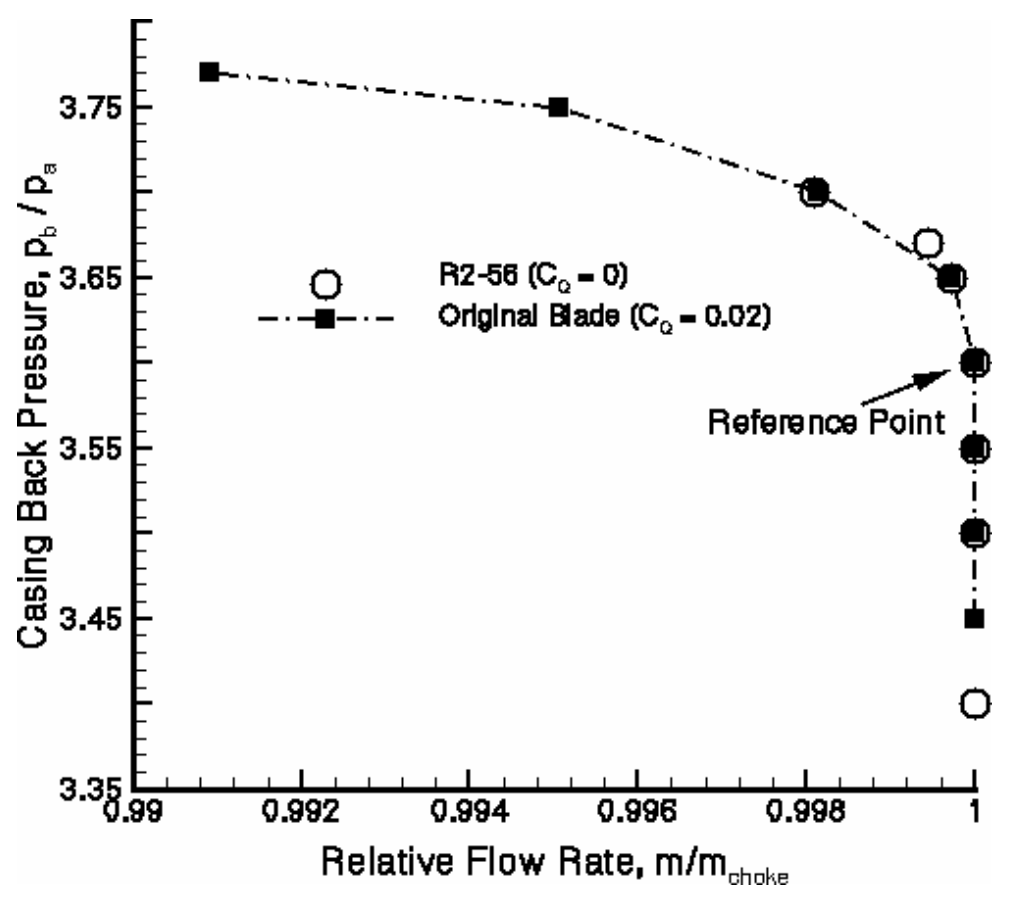

Figure 4.-Computed constant speed characteristic.

$$
\eta_{\max } \equiv \frac{\left(1-C_{Q}\right)\left[\left(P_{02} / P_{01}\right)^{\frac{\gamma-1}{\gamma}}-1\right]+C_{Q}\left[\left(P_{0 a s p} / P_{01}\right)^{\gamma-1} \gamma-1\right]}{\left(1-C_{Q}\right)\left[\left(T_{02} / T_{01}\right)-1\right]+C_{Q}\left[\left(T_{0 a s p} / T_{01}\right)-1\right]}
$$

In the above expression, a hypothetical process is assumed whereby the input power is partly used to compress the flow exiting the rotor and the aspirated flow to their individual pressure rise. The terms in the numerator characterize respectively the isentropic power required to compress the flow exiting the rotor with pressure ratio $\left(P_{02} / P_{01}\right)$, and the isentropic power required to raise the pressure of the aspirated flow to $\left(P_{\text {oass }} / P_{01}\right)$. Thermodynamic properties are obtained from the CFD results by mass-averaging the appropriate quantities over the stations of interest.

The lower limit for adiabatic efficiency is defined as the case where the aspirated flow is not thermodynamically useful and is expressed as:

$$
\eta_{\min } \equiv \frac{\left(1-C_{Q}\right)\left[\left(P_{02} / P_{01}\right)^{\frac{\gamma-1}{\gamma}}-1\right]}{\left(1-C_{Q}\right)\left[\left(T_{02} / T_{01}\right)-1\right]+C_{Q}\left[\left(T_{0 a s p} / T_{01}\right)-1\right]}
$$

Note that when the aspirated flow is absent (i.e. $C_{Q}=0$ ), the above relations reduce to the usual expression for adiabatic efficiency.

The CFD simulation indicated a spilled passage shock for the original blade at a casing back-pressure $\mathrm{p}_{\mathrm{b}} / \mathrm{p}_{\mathrm{a}}=3.60$. Thus, a critical situation (i.e., shock stability) necessitating flow control was established. At this back pressure, to pull the shock back inside the blade passage at a location similar to that of the $R 2$ 56 blade (shock position is in front of aspiration zone shown in Fig. 3), a suction amount of 2 percent of the incoming mass flow rate is needed. This level of aspiration is thus an add-on not only to prevent boundary layer separation, but also to directly accommodate the required increased circulation per blade. The computed constant speed (1290 ft/s) characteristic of the original blade with a suction coefficient $C_{Q}=0.02$ is shown in Figure 4 relative to that of the R2-56 blade. Note that the inlet mass flow rate is normalized by the maximum flow rate because the maximum flow rate of the original blade is higher due to the reduced metal and aerodynamic blockages. The original blade with 2 percent suction is able to sustain a higher static pressure rise with an increased throttling range. However, a suction coefficient, $\mathrm{C}_{\mathrm{Q}}=0.02$, is probably excessive in light of the available internal blade volume and unacceptable due to its potentially adverse system efficiency impact. Thus, a reference point $\left(\mathrm{p}_{\mathrm{b}} / \mathrm{p}_{\mathrm{a}}=3.60\right)$ as indicated in Figure 4 was selected for executing a redesign of the original blade with the goal of reducing the amount of flow suction.

A redesign of the original blade, referred to as the new design, was undertaken with the goal of recovering the performance of the $R 2-56$ blade while significantly reducing the amount of aspirated flow. The approach taken is to tailor a pressure-loading distribution in combination with suction that allows better shock management. A logical starting point is thus to compare the pressure loading distribution of the $R 2-56$ blade $\left(C_{Q}=0\right)$ with that of the original blade $\left(C_{Q}=0.02\right)$ at a casing back-pressure $\mathrm{p}_{\mathrm{b}} / \mathrm{p}_{\mathrm{a}}=3.60$, and then extract the desired features of an appropriate loading schedule to meet the new design goal. Figure 5 shows a comparison of the pressureloading distributions projected onto a meridional plane for the three cases.

The loading distribution for transonic blades operating in a started supersonic flow mode (i.e., establishment of an oblique shock pattern at the leading edge) can basically be decomposed into three interacting three-dimensional regions delineated as 

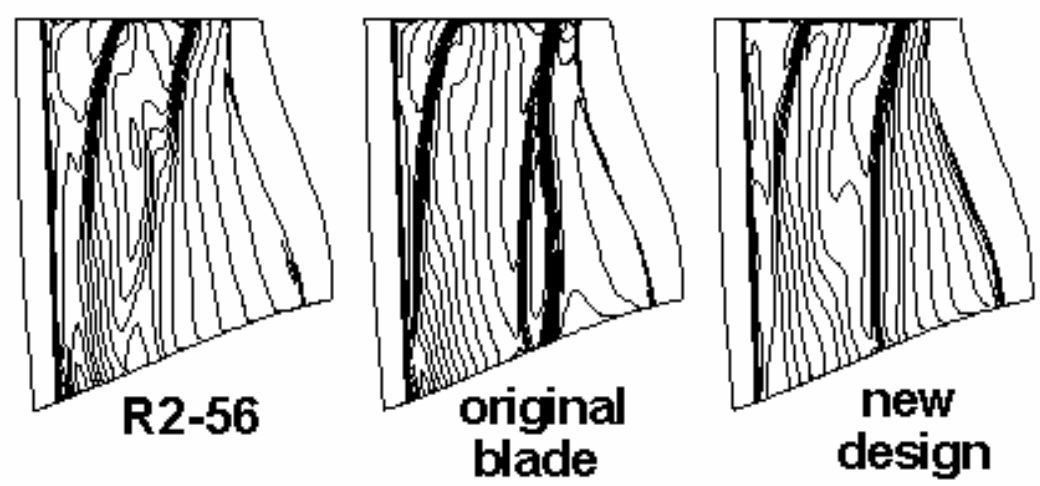

\section{Figure 5.-Comparison of blade loading distributions of original blade (INV3D analysis with $\mathrm{C}_{Q}=0.02$ ), new design (prescribed), and $R 2-56$ blade (INV3D analysis) at $\mathrm{p}_{\mathrm{b}} / \mathrm{p}_{\mathrm{a}}=\mathbf{3 . 6 0}$.}

entrance, core, and exit. A detailed description along with guidelines for integrating these various regions in a threedimensional viscous environment can be found in Medd [5]. The entrance region controls the flow induction capacity and establishes the transition to the first "discontinuity" of the core region that is associated with the pressure-surface leg of the passage shock. A second discontinuity corresponding to the suction-surface leg of the passage shock terminates the core region and sets up the aft pressure recovery schedule in the exit region. Placement of the passage shock can be controlled by moving the two "discontinuity" legs forward and backward, keeping the spread between these legs approximately the same. It can be observed from Figure 5 that the original blade has three "discontinuities" in its loading distribution as opposed to the two normally associated with the passage shock. The third discontinuity corresponds to the pressure gradient generated by the uniform mass flux aspiration required to prevent spillage of the passage shock. Also, large loading gradients indicative of relatively strong shocks are present in the loading distribution of the original blade. The loading distribution for the R2-56 blade indicates more moderate loading gradients in the core region and hence should offer superior shock management. Note that the spread of the core region is larger for the original blade due to the increased loading created by the reduced blade count. In addition, the aft loading in the exit region exhibits a smoother transition for the R2-56 blade akin to a more "controlled" diffusion.

Borrowing from the two loading distributions described above, a pressure-loading distribution was tailored for the new design and is also shown in Figure 5 for comparison. This figure shows that the placement of the passage shock in the new design is about the same as the original blade. The passage shock is weakened slightly in the tip region where the relative Mach number is high, and it is weakened considerably in the hub region where the relative Mach number is low. Note that this loading distribution is really a three-dimensional surface accounting for the multi-dimensionality of the flow and its tailoring is achieved via successive refinement. Currently, this refinement process and the selection of a suction coefficient to arrive at the new design take about a dozen tries by the authors. A more detailed comparison of the blade loading is given in Figure 6 at the 5, 50, and 95 percent span stations. It can be seen that the loading distribution for the new design is tailored to provide increased loading in the entrance and exit regions while lessening the loading in the core region. In addition, the magnitude of the jump across the two "discontinuities" is reduced, as mentioned earlier. As will be seen shortly, this reloading strategy has the effect of reducing the Mach number in front of the shock. This tailored loading distribution was prescribed in $I N V 3 D$ and then executed in the inverse mode to refine the original blade in an effort to meet the design goals.

The new design has the same meridional envelope, thickness distribution, and aspiration location as the original blade. A stacking line at approximately 50 percent chord was extracted from the original blade and prescribed for the new design. The redesign was first executed at the reference point $\left(\mathrm{p}_{\mathrm{b}} / \mathrm{p}_{\mathrm{a}}=3.60\right)$ without flow suction using the tailored pressureloading shape shown in Figure 5, and it was not successful. Small amounts of flow suction were successively applied until a converged solution was obtained. Success was achieved with a suction coefficient of $\mathrm{C}_{\mathrm{Q}}=0.003$.

The comparison of mass-averaged overall performance of the new design relative to $R 2-56$ and the original blade at the reference point is summarized in Table 1. Note that the overall performance of the new design, although slightly lower in pressure ratio (by about 0.2 percent), is very close to that of the $R 2-56$ blade. A range of adiabatic efficiencies, representing the lower and upper bounds previously defined, is given for the aspirated cases. The CFD results indicate a potential for significant improvement relative to the original blade. In particular, the adiabatic efficiency of the new design is increased over that of the original blade by 3 to 4 percent, depending on the utility of the aspirated flow. Clearly, the availability of the aspirated flow to perform useful work should be maximized in addition to minimizing the amount of power consumed to overcome aerodynamic losses. Questions which are beyond the scope of this paper still remain concerning the optimization and deployment of aspiration. 

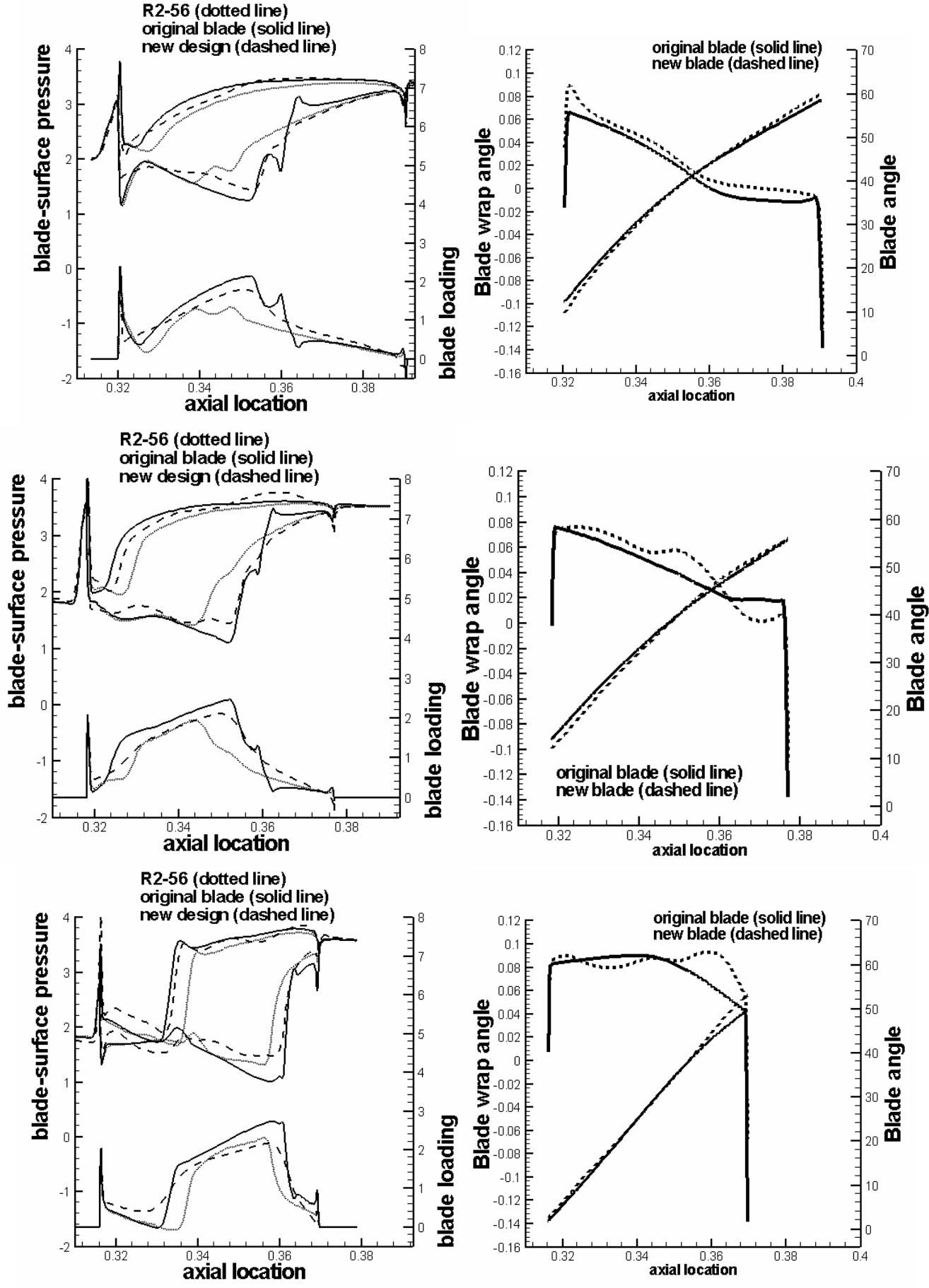

Figure 6.-Comparison of axial distribution of blade camber and pressure loading between $R 2-56$ blade, original blade, and new design at 5, 50, and 90 percent of span from hub. 
Table 1.-Comparison of Overall Performance (INV3D Analysis Mode) at $p_{b} / p_{a}=3.60$.

\begin{tabular}{|c|c|c|c|}
\hline & $\begin{array}{c}\text { Mass flow rate, } \\
\mathrm{lbm} / \mathrm{sec}\end{array}$ & $\begin{array}{c}\text { Pressure } \\
\text { ratio }\end{array}$ & $\begin{array}{c}\text { Adiabatic } \\
\text { efficiency, } \\
\text { percent }\end{array}$ \\
\hline $\begin{array}{c}\text { original } \\
\text { blade } \\
\mathrm{C}_{\mathrm{Q}}=0.02\end{array}$ & 74.9 & 2.077 & 89.5 to 91.3 \\
\hline $\begin{array}{c}\text { New } \\
\text { design } \\
\mathrm{C}_{\mathrm{Q}}=0.003\end{array}$ & 73.2 & 2.044 & 93.9 to 94.1 \\
\hline $\begin{array}{c}R 2-56 \text { blade } \\
\mathrm{C}_{\mathrm{Q}}=0.0\end{array}$ & 73.7 & 2.073 & 92.7 \\
\hline
\end{tabular}

To discern reasons why the new design indicates a significantly improved performance potential, the camber changes along with local aerodynamic diagnostics generated by $I N V 3 D$ are interrogated. Figure 6 shows a comparison of axial distributions of camber angle and pressure-loading between the new design, the original blade, and the $R 2-56$ blade. The increased loading due to the reduction in blade count can be seen along with a more severe suction-surface pressure gradient for the original blade and the new design. Also indicated for the new design, are the reduced camber rates for the same overall camber in the front part of the blade created to control suctionsurface acceleration. Note that the camber distribution for the new design automatically adapts to the local flow field with aspiration at the specified back pressure. It is clear from Figure 6 and Table 2 that the new design produces significantly lower peak Mach numbers than the original blade, especially near the blade tip. Thus, the shock management strategy built into the prescribed pressure-loading distribution is effective at reducing the shock strength. Less pressure recovery along the suction-surface is required for the new design thereby reducing the amount of aspiration relative to the original blade. Note that for the original blade, since the geometry was not adapted for the effects of reduced blade count, aspiration is an add-on not only for boundary layer control but also to accommodate the increased circulation per blade. The new design, being better matched to the conditions created by the reduced blade count, requires a smaller amount of suction strictly for boundary layer control.

Table 2.-Comparison of Peak Mach Numbers

\begin{tabular}{|c|c|c|c|}
\hline $\begin{array}{c}\text { Spanwise } \\
\text { station, } \\
\text { percent }\end{array}$ & $\begin{array}{c}\text { Original } \\
\text { blade peak } \\
\text { Mach no. }\end{array}$ & $\begin{array}{c}\text { New } \\
\text { design peak } \\
\text { Mach no. }\end{array}$ & $\begin{array}{c}R 2-56 \\
\text { blade peak } \\
\text { Mach no. }\end{array}$ \\
\hline 5 & 1.39 & 1.29 & 1.25 \\
\hline 50 & 1.54 & 1.37 & 1.39 \\
\hline 95 & 1.72 & 1.55 & 1.57 \\
\hline
\end{tabular}

Figure 7 compares passage Mach number distributions at 50 and 95 percent span stations. At all spanwise stations, the shock is significantly weakened due to the reduction in peak Mach number. In fact, it is seen that the peak Mach number in the new design is on the same order as the R2-56 blade. At the 95 percent span station, there is a weaker shock/leakage flow interaction resulting in a cleaner flow field for the new design.
This is also illustrated in Figure 8, which shows the Mach number distribution at the blade trailing-edge plane. The wake is thicker in the new design than in the original blade due to the fact that the suction coefficient is 2 percent for the original blade versus 0.3 percent for the new design. Thus, the improved aerodynamic quality of the new design is attributable to the features of the custom-tailored pressure-loading distribution leading directly to better shock management and its indirect effect on the three-dimensional flow structure.

For additional confirmation that the new design offers a superior performance potential, calculations were performed on the $R 2-56$ blade, the original blade, and the new design using $A D P A C$ with the same mesh as that employed for INV3D. Recall that the implementation of flow suction in $A D P A C$ can be different from $I N V 3 D$. Consequently, some care must be exercised when comparing results between INV3D and $A D P A C$. The $A D P A C$ results, shown as trailing-edge Mach number distribution in Figure 9, are for the most part, in agreement with those predicted by INV3D (Fig. 8). There are some differences in the tip clearance region, with $A D P A C$ indicating somewhat larger leakage related aerodynamic blockage. Mesh refinement in the clearance region did not significantly change this trend. Also, the new design shows a local bulge in the wake near the hub which was determined to be an artifact of the aspiration boundary condition in ADPAC. Closer inspection of the $A D P A C$ results indicated that flow blowing occurs near the hub! Again, this is a result of the different implementation of flow transpiration between ADPAC and $I N V 3 D$, as previously explained. It is not known whether this has any implications as to the practicality of the required spanwise distribution of suction over the aspirated zone. This discrepancy points to the need for a coupled analysis of the internal aspiration flow circuit with the external aerodynamics of the blading in order to achieve a reliable predictive capability.

Compared to the original blade, ADPAC predicts that the adiabatic efficiency potential of the new design is better by nearly 3 percent (using the definition $\eta_{\max }$ ). Similar to the $I N V 3 D$ results, the $A D P A C$ results show that the new design has a significantly cleaner casing-endwall flow region although its wake is slightly thicker relative to that of the original blade. The overall aerothermodynamic quality of the new design is thus better than that of the original blade at the reference point and its off-design characteristics should potentially be better, albeit using increased aspiration relative to the nominal 0.3 percent amount.

The final investigation demonstrates the use of flow aspiration to extend the constant speed $(1290 \mathrm{ft} / \mathrm{s})$ throttling range of the new design while keeping the same aerodynamic quality. By using flow suction up to 2 percent (amount needed by original blade to hold shock in blade passage at $\mathrm{p}_{\mathrm{b}} / \mathrm{p}_{\mathrm{a}}=3.60$ ), the passage shock position can be held "stationary" as the back pressure is increased from the reference value of 3.60 to around 3.75. Holding the shock "stationary" at the reference point conditions is expected to yield high aerodynamic quality since the blade was designed for this "operating" condition. Figure 10 shows the passage Mach number distributions at the 50 and 95 percent span stations for four different back pressures, along with the required suction coefficients to hold the shock "stationary." Table 3 shows the overall performance of this flow suction scheme. As the shock is forced to be 


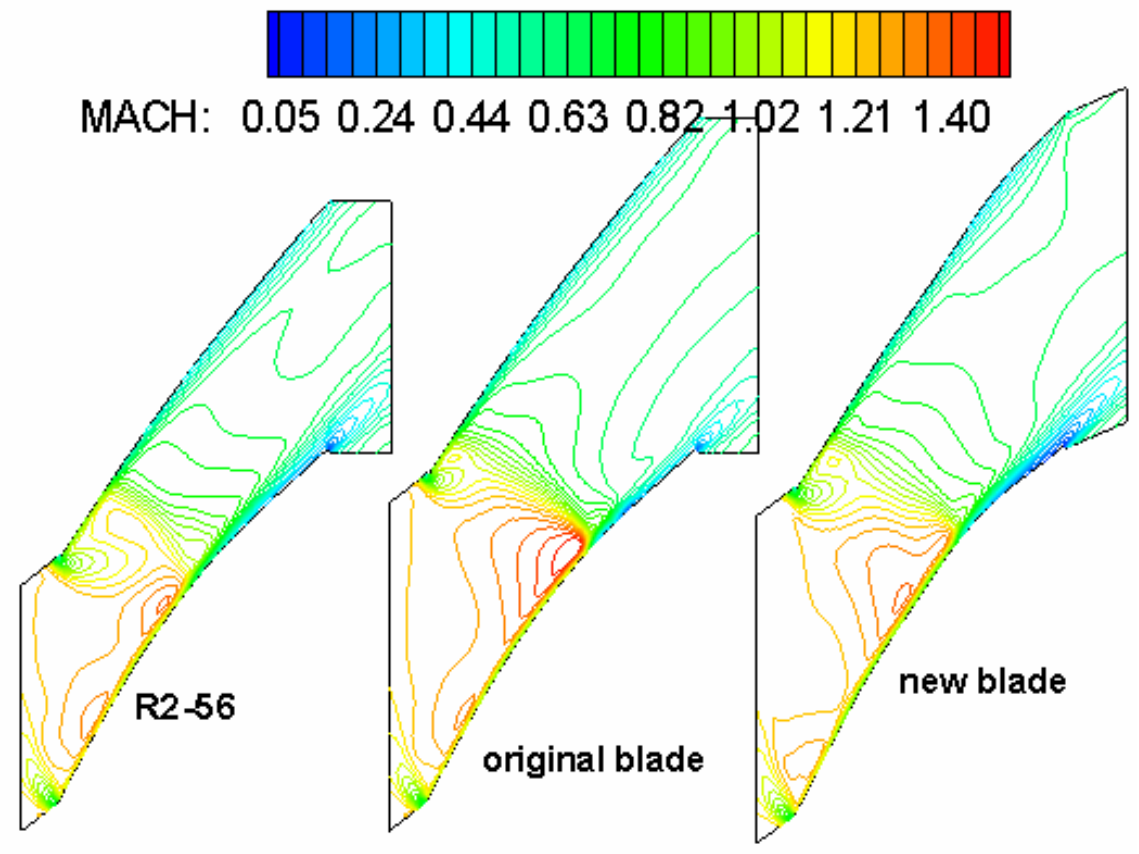

(a) 50 percent span from hub

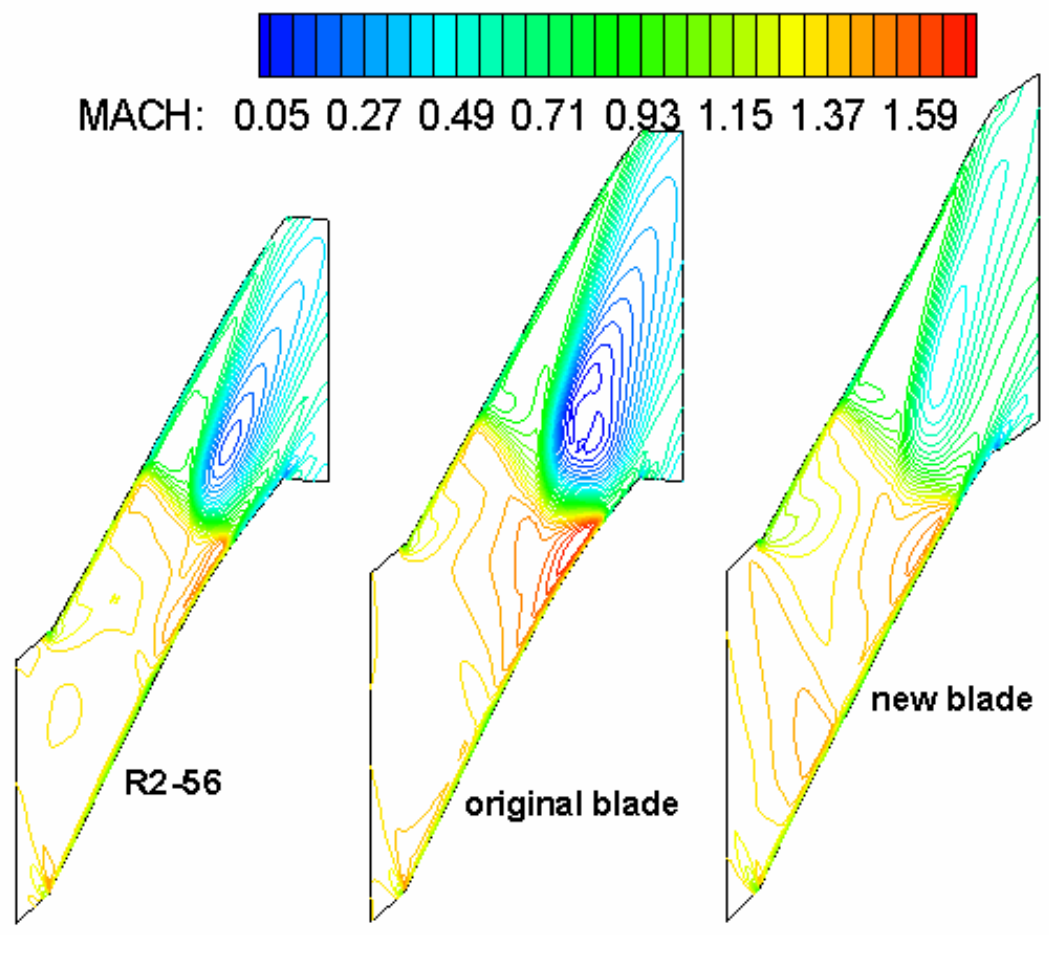

(b) 95 percent span from hub.

Figure 7.-Comparison of passage Mach number distributions at $p_{b} / p_{a}=3.60$. 
$\begin{array}{llllllllllll}\text { MACH: } \quad 0.10 & 0.17 & 0.24 & 0.32 & 0.39 & 0.46 & 0.53 & 0.61 & 0.68 & 0.75\end{array}$
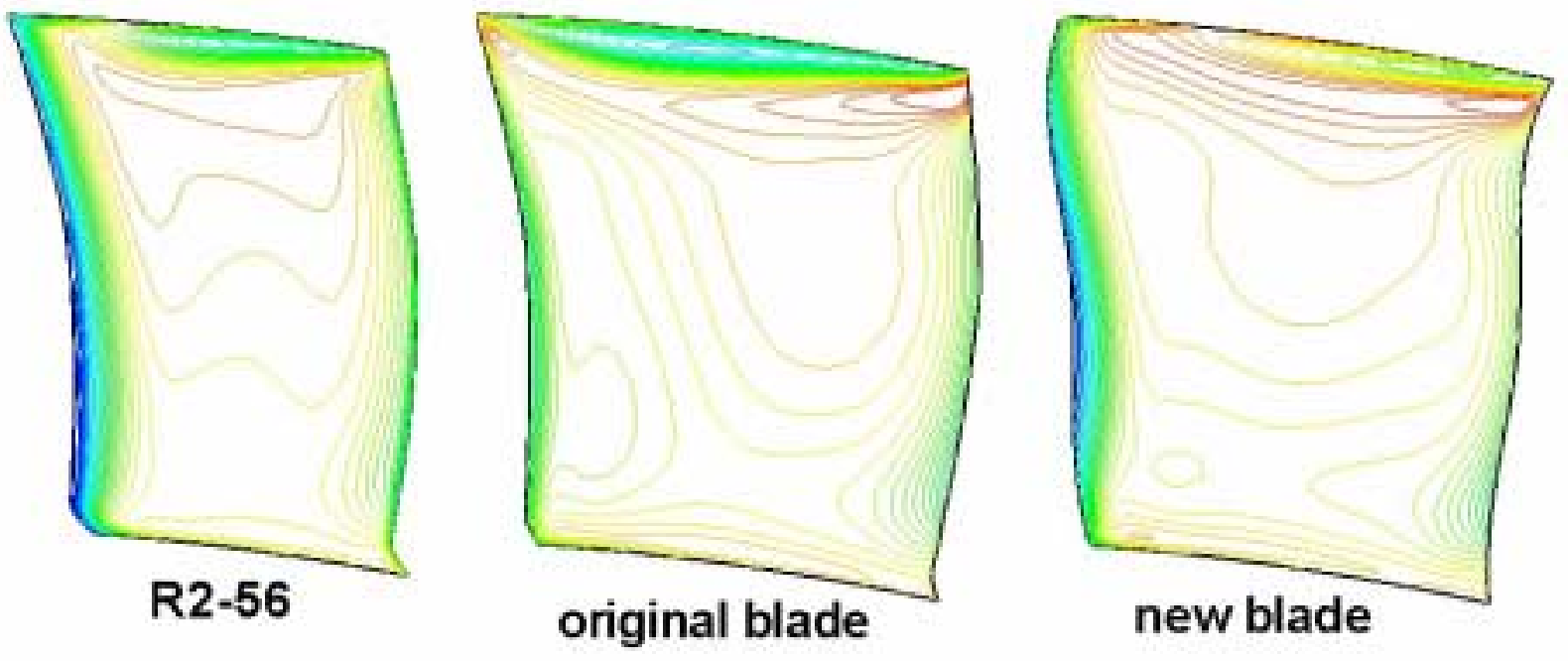

Figure 8.-INV3D prediction of trailing-edge Mach number distribution at $\mathrm{p}_{\mathrm{b}} / \mathrm{p}_{\mathrm{a}}=\mathbf{3 . 6 0}$.

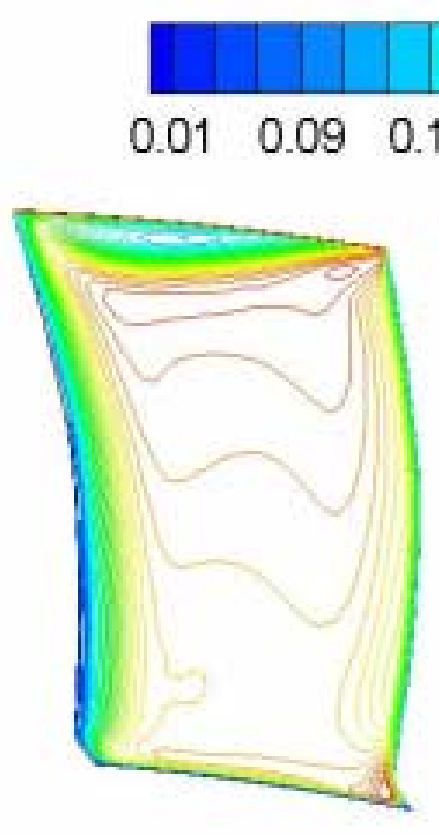

R2-56

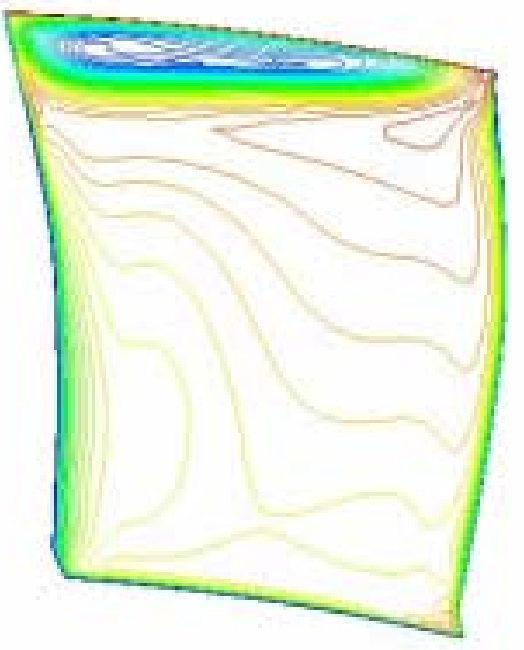

original blade

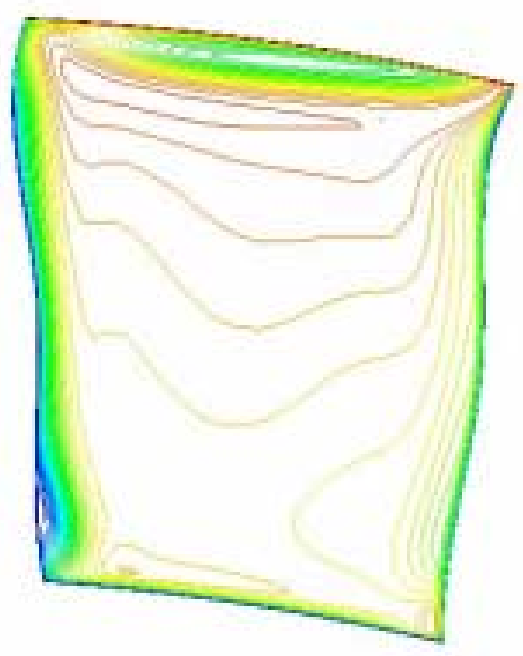

new blade

Figure 9.-ADPAC prediction of trailing-edge Mach number distribution. 

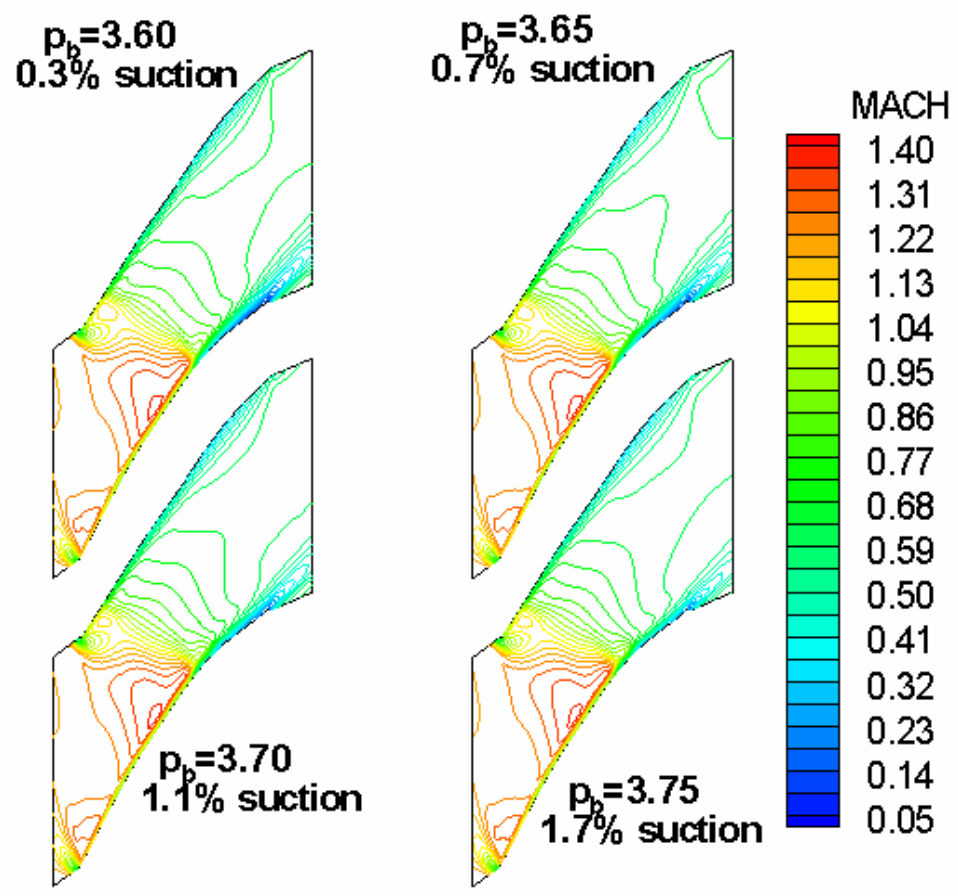

(a) 50 percent span from hub

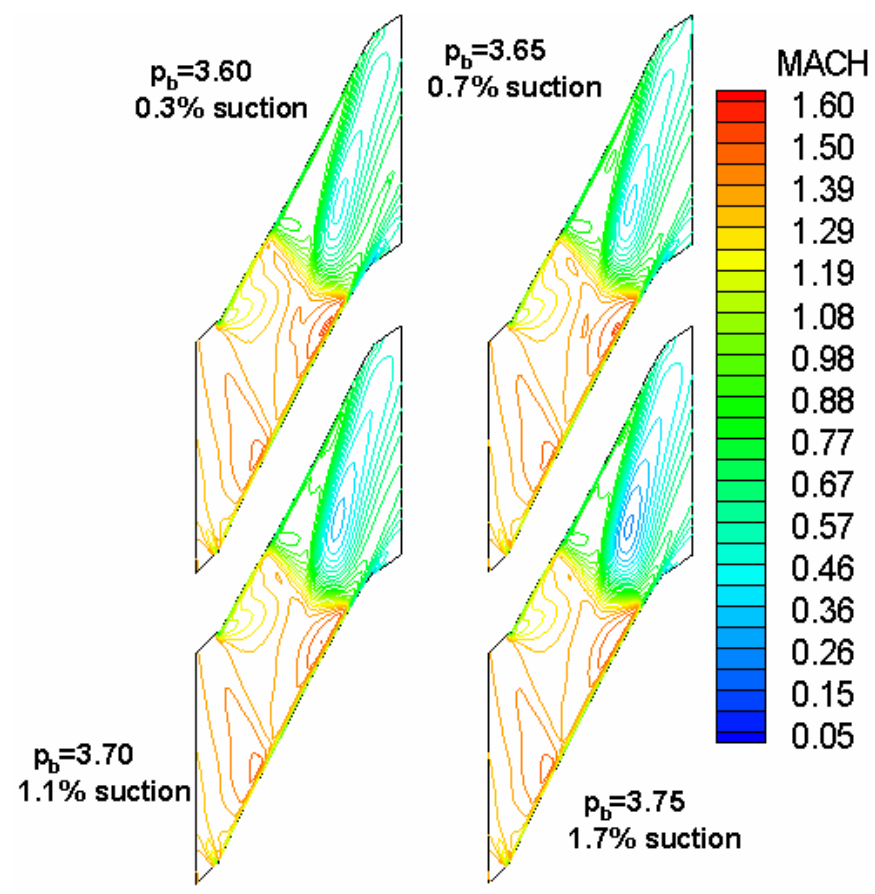

(b) 95 percent span from hub.

Figure 10.-Off-design performance of new design at constant speed for various back-pressures and prescribed suction coefficients.

Passage Mach number distributions at 95 percent span. 
Table 3.-Constant speed throttling performance of new design with varying suction coefficient to hold the

passage shock "stationary."

\begin{tabular}{|c|c|c|}
\hline $\begin{array}{c}\text { Casing, } \\
\mathrm{p}_{\mathrm{b}} / \mathrm{p}_{\mathrm{a}}\end{array}$ & $\begin{array}{c}\text { Suction coefficient, } \\
\mathrm{C}_{\mathrm{Q}} \\
\text { percent }\end{array}$ & Pressure ratio \\
\hline 3.60 & $0.3 \%$ & 2.044 \\
\hline 3.65 & $0.7 \%$ & 2.073 \\
\hline 3.70 & $1.1 \%$ & 2.104 \\
\hline 3.75 & $1.7 \%$ & 2.138 \\
\hline 3.77 & $2.0 \%$ & 2.152 \\
\hline
\end{tabular}

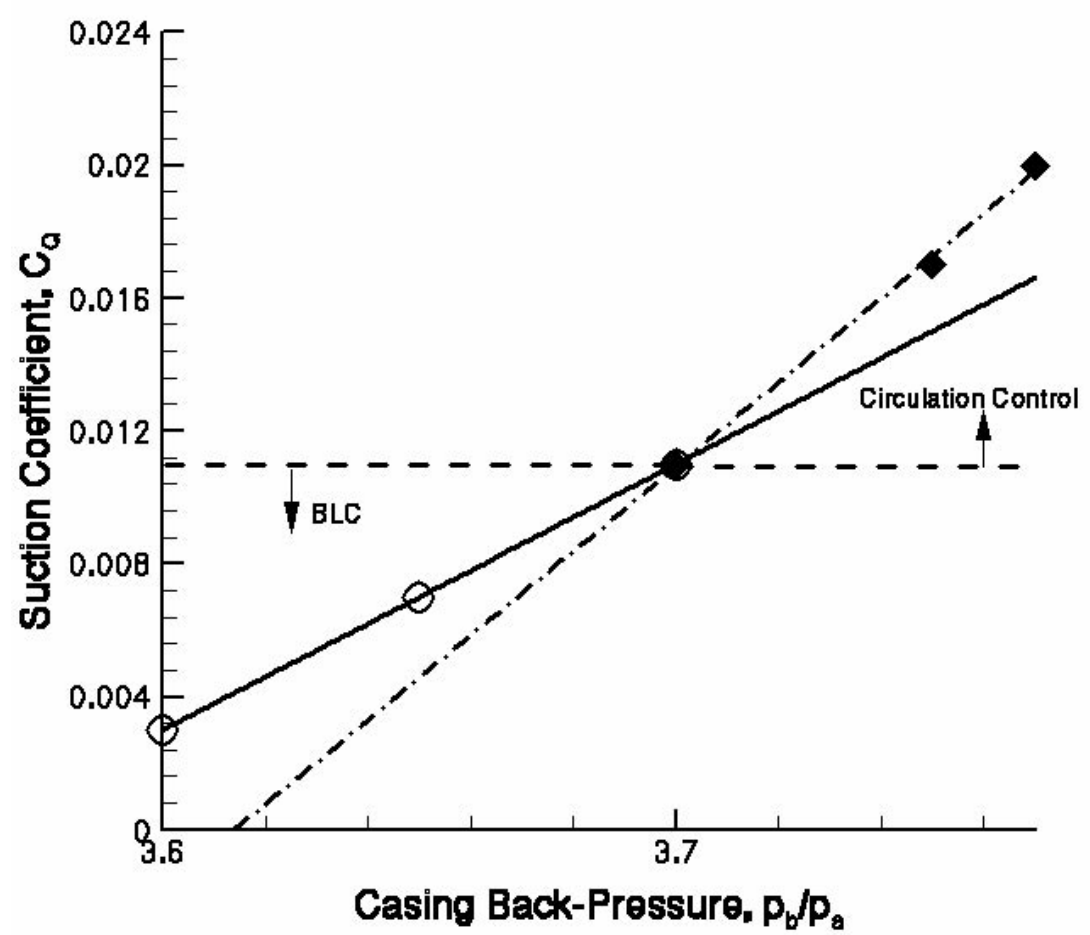

\section{Figure 11.-Variation of suction coefficient with back-pressure for "stationary" passage shock. Two flow control regimes: boundary layer control (BLC) and circulation control.}

"stationary" via variable suction flow rate, increasing back pressure leads to higher total pressure ratios.

Basically, suction surface aspiration is being used to uncouple the exit part of the pressure-loading region from the entrance and core regions. As can be observed from Figure 10, the exit part of the loading is that which is aft of the shock impingement on the suction surface. An interesting trend can be observed from Figure 11 which shows the variation of suction coefficient, $\mathrm{C}_{\mathrm{Q}}$, with back-pressure. Note that the passage shock spills at a back-pressure of approximately $\mathrm{p}_{\mathrm{b}} / \mathrm{p}_{\mathrm{a}}=3.7$ for the $R 2$ 56 blade without aspiration (Fig. 4). Two flow control regimes, delineated by the abrupt change in the slope of the curve, can be identified as boundary layer control (BLC) and circulation control. For back pressures less than $\mathrm{p}_{\mathrm{b}} / \mathrm{p}_{\mathrm{a}}=3.7$, a close look at
Figure 10(a) indicates that shock/boundary layer interaction is progressively suppressed. Beyond $\mathrm{p}_{\mathrm{b}} / \mathrm{p}_{\mathrm{a}}=3.7$, shock/boundary layer interaction is completely suppressed without any direct effect of the profile boundary layer on the pressure rise. The BLC regime is observed to be thermodynamically more efficient than circulation control. In general, a smaller suction flow investment is required for BLC. Thus, understanding the mechanisms responsible for establishing the slope of the line in the BLC regime and how they relate to the blading design (i.e., solidity, aspect ratio, and shaping) is key to achieving further performance gains with just the "right" amount of aspiration. Figure 11 suggests the possibility of customizing the amount of flow aspiration for each spanwise station. A discussion of this is reserved for future work. 


\section{SUMMARY}

A three-dimensional viscous inverse method was extended to include transpiration boundary conditions thereby allowing blading design with full interaction between the prescribed pressure-loading distribution and a specified transpiration scheme. An exposition of the basic method was given with further refinements to follow at a later time. To illustrate the potential merits of this method, the design and analysis of a highly-loaded supersonic compressor rotor with aspiration was presented. The goal of this exercise was to demonstrate that aspiration, when used as an add-on to an existing design can require excessive amounts of suction, whereas, with a tailored pressure-loading distribution combined with the aspiration scheme and executed with the inverse design method, a significantly lower amount of suction is needed.

A baseline supersonic rotor with 56 blades called $R 2-56$ was used as the starting point. The blade count in this rotor was then reduced to 42 blades, and it was found that 2 percent of flow suction is needed to pull the shock back into the blade passage for the required back pressure. The aspiration zone was located approximately behind the shock on the suction surface from hub to 95 percent span. With 42 blades, inspection of the flow field showed that the peak Mach number and loading are significantly higher than in the $R 2-56$ blade case, resulting in increased shock losses, thickening of the blade suction-surface boundary layer, and a large region of low-momentum fluid in the tip-clearance region. A new pressure-loading shape was developed to mitigate the situation. The new design was shown to have better efficiency potential and a cleaner casing endwall flow using only 0.3 percent flow suction. It was also shown that the constant speed throttling characteristic of the new design can be tailored by using varying amounts of suction (up to 2 percent) to hold the passage shock "stationary" thereby making it possible to satisfy multiple operating conditions with minimal "aerodynamic" penalty.

\section{REFERENCES}

1. Kerrebrock, J.L., Reijnen, D.P., Ziminsky, W.S., and Smilg, L.M., 1997, "Aspirated Compressors," ASME Paper 97-GT-525.

2. Merchant, A.A., 2002, "Aerodynamic Design and Performance of Aspirated Airfoil," ASME paper 2002GT-30369.

3. Loughery, R.J., Horn, R.A., and Tramm, P.C., 1971, "Single Stage Experimental Evaluation of Boundary Layer
Blowing and Bleed Techniques for High Lift Stator Blades," NASA CR-54573.

4. Dang, T., Damle, S., and Qiu, X., 2000, "Euler-Based Inverse Method for Turbomachine Blades: Part II-Three Dimensions," AIAA Journal, 38, no. 11.

5. Medd, A.J., 2002, "Enhanced Inverse Design Code and Development of Design Strategies for Transonic Compressor Blading," Ph.D. dissertation, Department of Mechanical Engineering, Syracuse University.

6. Jameson, A., Schmidt, W., and Turkel, E., 1981, "Numerical Solution of the Euler Equations by Finite Volume Methods Using Runge-Kutta Time-Stepping Schemes," AIAA Paper 81-1259.

7. Denton, J.D., 1992, "The Calculation of Three Dimensional Viscous Flow Through Multistage Turbomachines," ASME Journal of Turbomachinery, 114, pp. 18-26.

8. Hall, E.J. and Delaney, R.A., 1995, "Investigation of Advanced Counterrotation Blade Configuration Concepts for High Speed Turboprop Systems: Task VII-ADPAC User's Manual," NASA CR-195472.

9. Dang, T.Q., 1995, "Inverse Method for Turbomachine Blades Using Shock-Capturing Techniques," AIAA Paper 95-2465.

10. Qiu, X., 1999, "Improved Algorithm for ThreeDimensional Inverse Method," Ph.D. dissertation, Department of Mechanical Engineering, Syracuse University.

11. Qiu, X. and Dang, T., 2000, “3D Inverse Method for Turbomachine Blading with Splitter Blades," ASME Paper 2000-GT-526.

12. Damle, S., Dang, T., Stringham, J., and Razinsky, E., 1999, "Practical Use of a 3D Viscous Inverse Method for the Design of Compressor Blade," ASME Journal of Turbomachinery, 121, no. 2, April 1999.

13. Medd, A.J., Dang, T.Q., and Larosiliere, L.M., 2003, “3D Inverse Design Loading Strategy for Transonic Axial Compressor Blading," submitted to ASME Journal of Turbomachinery.

14. Larosiliere, L.M., Wood, J.R., Hathaway, M.D., Medd, A. J., and Dang, T.Q., 2002, "Aerodynamic Design Study of an Advanced Multistage Axial Compressor," NASA TP211568 . 


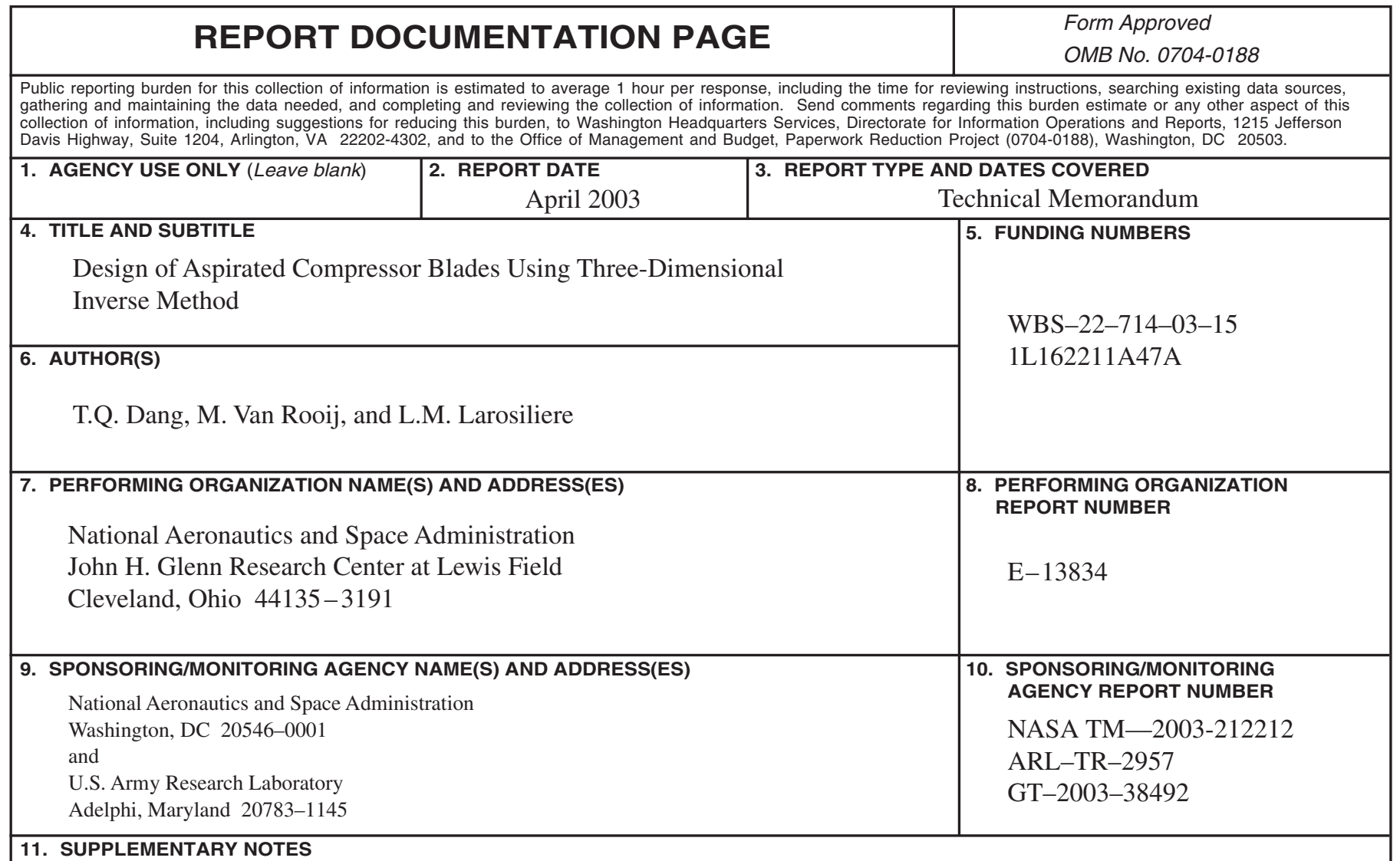

\section{SUPPLEMENTARY NOTES}

Prepared for the Turbo Expo 2003 cosponsored by the American Society of Mechanical Engineers and the International Gas Turbine Institute, Atlanta, Georgia, June 16-19, 2003. T.Q. Dang and M. Van Rooij, Syracuse University, Syracuse, New York 13244; L.M. Larosiliere, U.S. Army Research Laboratory, NASA Glenn Research Center. Responsible person, L.M. Larosiliere, organization code 0300, 216-433-3403.

\begin{tabular}{ll|l}
\hline 12a. DISTRIBUTION/AVAILABILITY STATEMENT & & 12b. DISTRIBUTION CODE \\
Unclassified - Unlimited & Distribution: Nonstandard & \\
Subject Category: 02 & \\
Available electronically at http://gltrs.grc.nasa.gov & \\
This publication is available from the NASA Center for AeroSpace Information, 301-621-0390. &
\end{tabular}

\section{ABSTRACT (Maximum 200 words)}

A three-dimensional viscous inverse method is extended to allow blading design with full interaction between the prescribed pressure-loading distribution and a specified transpiration scheme. Transpiration on blade surfaces and endwalls is implemented as inflow/outflow boundary conditions, and the basic modifications to the method are outlined. This paper focuses on a discussion concerning an application of the method to the design and analysis of a supersonic rotor with aspiration. Results show that an optimum combination of pressure-loading tailoring with surface aspiration can lead to a minimization of the amount of sucked flow required for a net performance improvement at design and offdesign operations.

\begin{tabular}{|c|c|c|}
\hline \multicolumn{3}{|c|}{$\begin{array}{l}\text { 14. SUBJECT TERMS } \\
\text { Compressor aerodynamics; Inverse des }\end{array}$} \\
\hline $\begin{array}{l}\text { 17. SECURITY CLASSIFICATION } \\
\text { OF REPORT } \\
\text { Unclassified }\end{array}$ & $\begin{array}{l}\text { 18. SECURITY CLASSIFICATION } \\
\text { OF THIS PAGE } \\
\text { Unclassified }\end{array}$ & $\begin{array}{l}\text { 19. SECURITY CLASSIFICATION } \\
\text { OF ABSTRACT } \\
\text { Unclassified }\end{array}$ \\
\hline
\end{tabular}

